\title{
Effects of Major Grassland Conservation Programs Implemented in Inner Mongolia since 2000 on Vegetation Restoration and Natural and Anthropogenic Disturbances to Their Success
}

\author{
Liqun Shao, Haibin Chen, Chen Zhang and Xuexi Huo * \\ College of Economics and Management, Northwest A\&F University, Yangling 712100, China; \\ skirtshao@nwafu.edu.cn (L.S.); hbchen@nwafu.edu.cn (H.C.); zhangchen92@nwafu.edu.cn (C.Z.) \\ * Correspondence: xuexihuo@nwafu.edu.cn; Tel.: +86-29-8708-1059; Fax: +86-29-8708-1209 \\ Academic Editor: Vincenzo Torretta \\ Received: 18 November 2016; Accepted: 17 March 2017; Published: 21 March 2017
}

\begin{abstract}
Several grassland conservation programs aiming to relieve grazing pressure have been implemented in Inner Mongolia since 2000 to reverse grassland degradation and protect local and regional environments. Previous studies on the effects of these programs usually used small-scale data generated from field experiments and household surveys, inhibiting the discovery of large-scale effects due to spatial heterogeneity. For a typical study region in Xilingol League, we used fixed-effects models and a panel dataset at the county level from 1998 to 2013 to examine the effects of two programs, namely, the Beijing-Tianjin Wind/Sand Source Control Program and the Ecological Subsidy and Award System and other drivers on vegetation rehabilitation. The modeling results suggested that the programs had a positive but delayed impact on grassland vegetation rehabilitation. Enrollment in the two programs in a specific year was predicted to increase the vegetation index value by amounts equivalent to $186 \mathrm{~mm}$ and $98 \mathrm{~mm}$ more annual precipitation after two years, respectively $(p<0.01)$. Fixed effects (including site factors and land use history) had a greater effect, hence the design and implementation of government conservation policies should be context-based.
\end{abstract}

Keywords: grassland conservation; grazing exclusion; normalized difference vegetation index; fixed effects model

\section{Introduction}

Degradation of arid grazing lands is commonly described in terms of loss of palatable perennial plants, invasion of undesirable plant species and soil erosion [1]. The global impact of this degradation is significant, as arid rangelands (including grasslands, savannas, and shrublands) comprise approximately $80 \%$ of the world's rangelands [2] and support approximately half of the world's livestock [3]. Vegetation is the primary resource and stability factor in these rangelands, providing additional services such as rainfall interception, control of water infiltration and runoff, as well as regulation of local climate [4]. Because grazing shifts most of the primary production from vegetation to livestock, it limits vegetation services and is widely recognized as a primary cause of rangeland degradation [5-7]. Since rangeland degradation proceeds in steps, and is increasingly difficult and costly to reverse [8], taking measures promptly is necessary. While there are numerous publications about the fact that recovery of degraded land is impossible or very slow [9-11], grazing pressure relief is still the dominant strategy to remedy rangeland degradation worldwide.

Inner Mongolia of China is a case in point. Its grassland covers an area of 78 million ha and accounts for $21.7 \%$ of China's total grassland area, supporting this ethnic region as the largest of the country's five major pastoral regions [12]. However, due to rapid population growth, intensive and 
improper anthropogenic activities (mainly grazing and reclamation), and adverse effects of droughts exacerbated by climate change [13-16], approximately $90 \%$ of Inner Mongolia's natural grassland has been degraded to some extent $[17,18]$. Acknowledged as an important ecological barrier for northern China, grassland degradation of this magnitude can cause several regional or even global environmental problems $[19,20]$, of which the most prominent is the frequent occurrence of severe sandstorms and dust storms sweeping across northern China in recent decades, especially around Beijing and adjacent regions. Besides environmental impacts, such degradation can also directly affect the livelihood of millions of people, especially indigenous ethnic Mongolians who have lived in the region for generations [13].

To prevent grassland degradation and to recover the ecological services provided by the grassland ecosystem, several nationwide major grassland conservation programs have been implemented in the Inner Mongolian region since 2000, including the Beijing-Tianjin Wind/Sand Source Control Program (hereafter, BTWSSC) since 2001, the Grazing Withdrawal Program since 2003, and the Ecological Subsidy and Award System (hereafter, ESAS) since 2011. These programs could be categorized into rehabilitation initiatives according to Aronson et al. [21], where unlike restoration-which aims for a complete return of a site to a defined indigenous, historic state-rehabilitation seeks to repair damaged or blocked ecosystem functions, with the primary goal of raising ecosystem productivity for the benefit of local people. Rehabilitation normally implies a higher level of ongoing site management than does restoration, wherein it is hoped that innate ecosystem process will eventually take over. A comprehensive examination of these major grassland conservation programs reveals a basic logic underlying their introduction that was based on an assumption that overgrazing was the fundamental cause of grassland degradation [22]. Therefore, grazing controls through year-round or seasonal grazing cessation, rotational grazing and achieving a forage-livestock balance were the major counter-measures implemented to restore the grassland vegetation condition, and all aimed to reduce the grazing pressures on grasslands. The different timings and spatial configurations of the programs present an unusual setting of a quasi-natural policy experiment. It is very interesting and promising to explore the impacts of these programs and other drivers, therein to examine the effectiveness of grazing pressure relief on a regional scale, which is what we intended to accomplish in this study.

Controversy exists in previous studies about the ecological effects of the programs [22]. While many scholars suggest that the grassland conservation programs have had positive impacts on restoring grassland vegetation [23-26], others argue that these programs have generated negative impacts on the larger scale ecosystem. Critics of the programs point out that grazing pressures were shifted to non-program areas, thus increasing grassland degradation in non-program areas, and that illegal grazing activities were common [27-29]. In addition, some researchers believe that long-term grazing exclusion is harmful to vegetation regeneration and is unsustainable $[27,30]$, and a moderate stocking rate is needed to encourage the complementary growth of plants and sustainable use of grassland [31,32]. The effectiveness of grazing pressure relief on grassland vegetation rehabilitation still needs to be verified. Most arid and sub-arid rangelands show non-equilibrium behaviors [33] in which short-term rainfall variability imposes dramatic changes in vegetation covers that mask the true contribution of grazing pressure relief [34]. The driving forces of grassland degradation or regeneration and their relative contributions are still unclear and context-based [35,36], and detection of the effects of grassland rehabilitation programs has been hampered because the impacts of all relevant factors have not been controlled.

Most previous studies of the conservation programs in Inner Mongolia used small-scale data generated from field experiments and household surveys. With such datasets, it was difficult to elucidate the large-scale effects of the programs, or to scale results up to regional levels due to spatial heterogeneity. This study uses a panel dataset and a fixed effects model to clarify the respective effects of the two major grassland conservation programs (the BTWSSC and ESAS) as well as other drivers on vegetation rehabilitation in Xilingol League, a typical steppe region of Inner Mongolia. The panel dataset consists of the normalized difference vegetation index (NDVI) obtained from 
the SPOT satellite (SPOT-VEGETATION NDVI), multi-station surface meteorological observations, socio-economic statistical data, as well as the implementation duration and range of major grassland conservation programs at county level for the period 1998-2013. This data record begins three years before the initiation of the BTWSSC program and extends to two years after the initiation of the ESAS program. Although NDVI is frequently criticized as inadequate for understanding changes in structure and composition, as well as other complex ecological processes in degrading grasslands [37,38], most studies are still based on it [39-41], and we use it as a proxy of the coverage and productivity of aboveground vegetation. In econometrics, fixed effects models usually assist in controlling for unobserved heterogeneity when this heterogeneity is constant over time [42]. Fixed effects assumptions were considered appropriate for the study, given that the unobserved heterogeneity of all counties in the League is not fully independent of the explanatory variables (NDVI). In particular, the geomorphological variables are usually believed to be temporally constant but play an important role in shaping surface vegetation. For historical reasons, counties may have very different vegetation status, and historical factors are also effectively captured by the fixed effects. It is hoped that, with the empirical data and econometric modelling method, this study will improve our knowledge of the effectiveness of government conservation policy as well as the relative contributions of other drivers at a regional scale, and help to design and implement policy more effectively, and ultimately, to achieve better resource conditions.

The methodological framework followed here is described in Section 2, with results and discussion being presented in Sections 3 and 4, respectively, and conclusions provided in Section 5.

\section{Materials and Methods}

\subsection{Study Area}

Xilingol League is located in the middle of the Inner Mongolia Autonomous Region, directly north of Beijing $\left(111^{\circ} 59^{\prime}-120^{\circ} 00^{\prime} \mathrm{E}, 42^{\circ} 32^{\prime}-46^{\circ} 41^{\prime} \mathrm{N}\right)$. The human population was 1.03 million in 2013 , of which ethnic Mongolians accounted for 31\%. The League is comprised of two municipalities (Erenhot and Xilinhot), nine banners (Abag, Sonid Left, Sonid Right, East Ujimqin, West Ujimqin, Taibus, Bordered Yellow, Plain and Bordered White, and Plain Blue) and one county (Duolun), all of which are at the same administrative level as a county (Figure 1) and hereafter will be referred to as counties. Taibus is classified as a semi-pastoral county, and Erenhot and Duolun are classified as non-pastoral counties, in which Erenhot is an urban district and Duolun is a county dominated by crop farming. All other areas are classified as pastoral counties. Extensive grazing dominates the agricultural sector of pastoral counties. However, in the semi-pastoral county of Taibus, more intensive animal husbandry is practiced and dominates grassland use. Furthermore, crop farming is more pervasive in Taibus.

Xilingol League experiences an arid and semi-arid continental climate. The annual average temperature is $1-4{ }^{\circ} \mathrm{C}$, and there is a large daily temperature difference in the summer and freezing temperatures in winter. Annual precipitation ranges between 150 and $400 \mathrm{~mm}$, varying greatly among years and concentrated from June to August. Precipitation demonstrates a declining gradient from east and south to west and north.

The grassland area is $197,000 \mathrm{~km}^{2}$, accounting for $97 \%$ of the League's total land area. The area of available pasture is $180,000 \mathrm{~km}^{2}$, accounting for more than $25 \%$ of that in Inner Mongolia. Grassland animal husbandry is the League's major agricultural industry and an important livelihood source for rural residents. After implementation of the Household Production Responsibility System, the amount of livestock increased rapidly, from 2 million sheep units in 1977 to 18 million sheep units in 2000 [43]. In addition to the intensification of animal husbandry, the scale of crop farming has continually increased, reclaiming comparatively more grassland in recent decades, resulting in increased grain production (Figure 2). According to data for 2011, the areas of degraded grassland, desertified grassland, and salinized grassland were 11.18, 2.55, and 0.77 million ha, respectively, accounting for $57.93 \%, 13.22 \%$, and $3.99 \%$ of total grassland area, respectively [44]. 


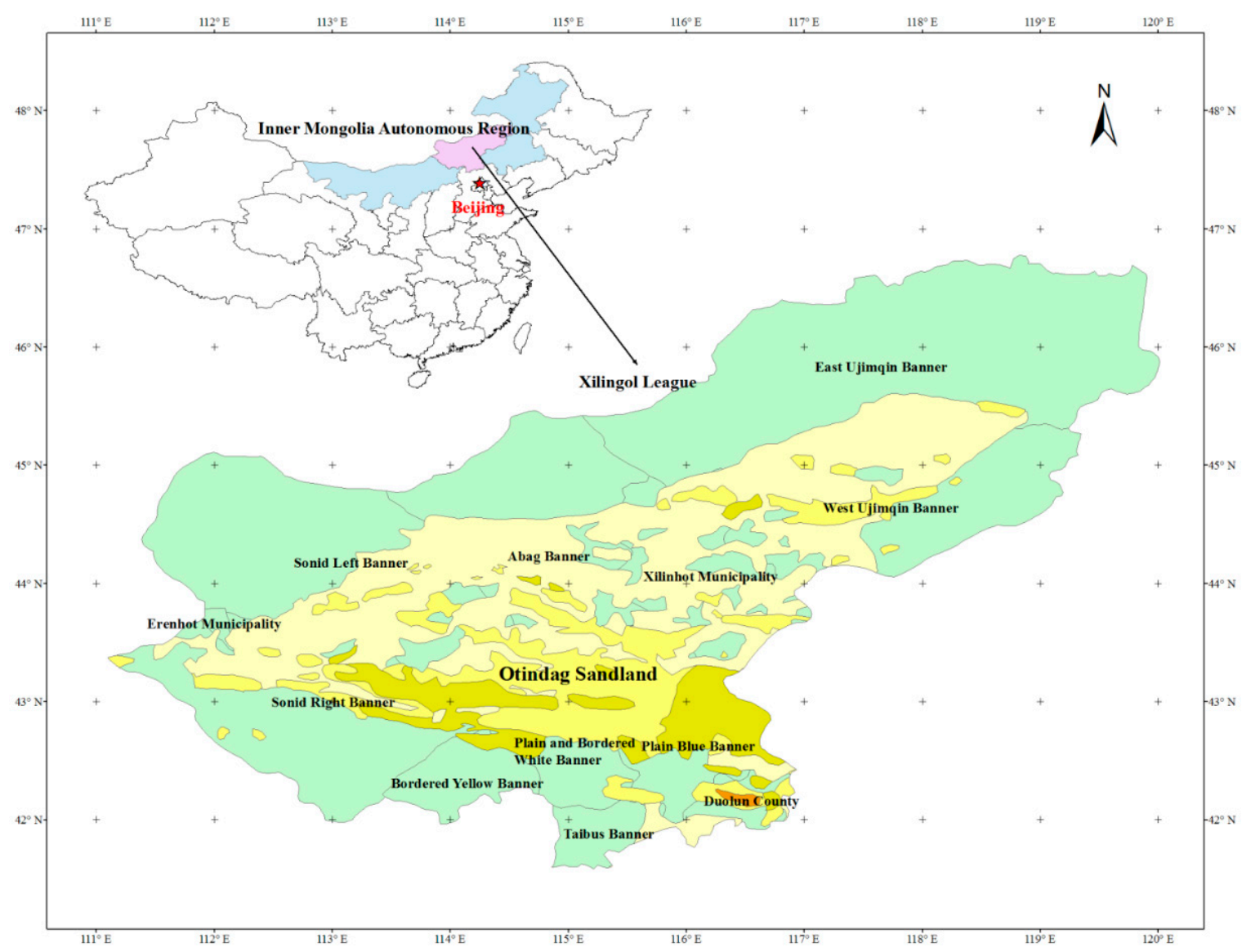

Figure 1. Geographic location of Xilingol League and its administrative divisions.

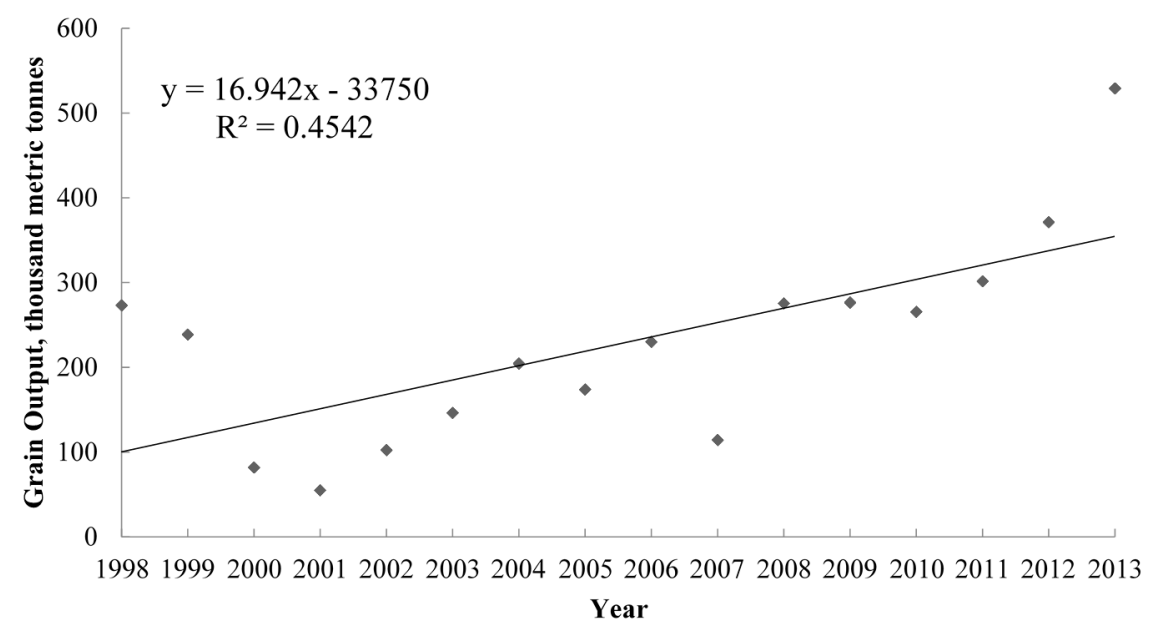

Figure 2. Total grain output of Xilingol League (1998-2013).

Due to the geographical location of Xilingol League, grassland degradation of the magnitude experienced in the region directly affects the environmental quality of Beijing and adjacent regions, and contributes directly to the frequency and severity of dust and sand storms around Beijing. As a response, the first program, BTWSSC, was introduced and implemented in five peripheral provinces and covered a total area of 458,000 $\mathrm{km}^{2}$. In Inner Mongolia, $369,000 \mathrm{~km}^{2}(31.9 \%$ of the total area) was registered in BTWSSC, accounting for $80.6 \%$ of the program's total implemented area. In the first stage of this program (2001-2010), the central government invested 41.2 billion Yuan (1 Yuan = 0.15 USD), 
which was ear-marked to subsidize, among other things, grazing cessation, construction of grassland enclosures and pens for livestock, human emigration and resettlement from areas in which grazing was banned, aerial seeding, and establishment of cultivated pastures [45]. The second stage of BTWSSC began in 2013 with a planned expiration in 2022 and a budget of 87.8 billion Yuan [46].

The ESAS program began in 2011, targeting more extensive grasslands and dramatically increasing investment in grassland restoration with an annual budget of 13.6 billion Yuan. The actual expenditure by the ESAS was 14.9 billion Yuan in 2012 [47], which exceeded the budget arrangement. In addition

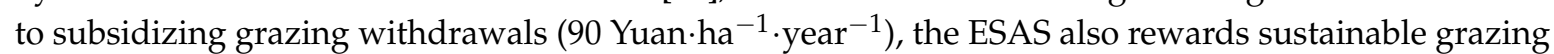
practices (22.5 Yuan $\cdot \mathrm{ha}^{-1}$.year ${ }^{-1}$ ) based on grassland carrying capacity (so-called forage-livestock balance), subsidizes purchasing improved livestock breeds (800 Yuan head $^{-1}$.year ${ }^{-1}$ for breeding rams and 50 Yuan head $^{-1}$.year ${ }^{-1}$ for breeding cows in Inner Mongolia), supports improved perennial grass cultivation (1050 Yuan.ha ${ }^{-1}$ for three years in Inner Mongolia), and gives grants for other comprehensive production materials (500 Yuan $\cdot$ household $^{-1} \cdot$ year $^{-1}$ in Inner Mongolia). The ESAS also provides funds for herders' vocational education and training. In total, 56.6 million ha of grasslands were registered in the ESAS program, including 18.6 million ha for grazing bans and 38 million ha in the forage-livestock balance scheme. In addition, 6 million ha of grassland were transferred into the ESAS program from the Grazing Withdrawal program [48].

In summary, all 12 counties participated in both stages of the BTWSSC program as well as the ESAS program. Due to implementation of these programs, the momentum of rapid growth in livestock numbers in Xilingol League was effectively reversed, and, in fact, the total number of animals decreased since 2000, from 11.88 million head in 1999 to 7.08 million head in 2013 (Figure 3).

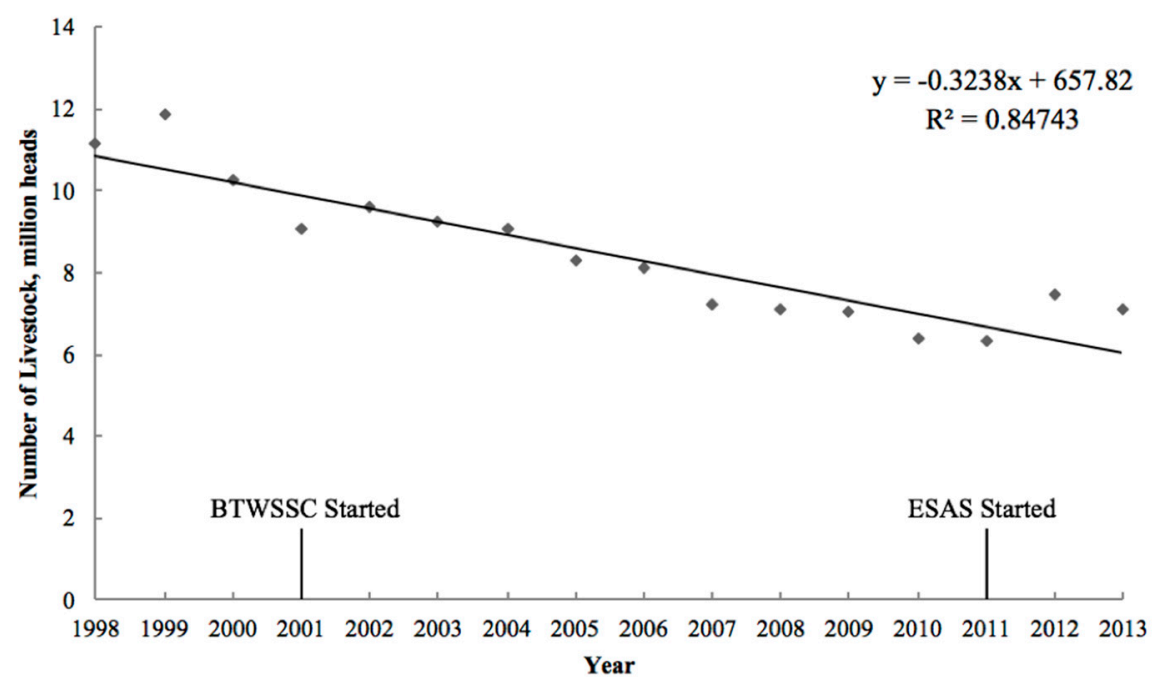

Figure 3. Number of livestock in Xilingol League (1998-2013). Data source: Statistical Year Book of Inner Mongolia (1999-2014).

\subsection{Specification of Fixed Effects Models}

A fixed-effects model was employed to quantify the impacts of major natural and anthropogenic factors on grassland vegetation change of Xilingol League. The NDVI was selected as a dependent variable. Increasingly positive NDVI values indicate increasing amounts of green vegetation. NDVI values near zero and more negative values indicate lower vegetation coverage or non-vegetated features such as barren surfaces (rock and soil) and water, snow, ice, and clouds. As previous studies suggested, grazing intensity, human population density, crop farming intensity, and industrial activity intensity are the major anthropogenic driving forces of grassland vegetation change, and precipitation is the major natural driving force for grassland vegetation change in this arid region. Because the major implementation objective of the BTWSSC and ESAS programs was to control the number of livestock, 
in this study, the variable of grazing intensity was replaced with dummy variables that represented the programs' implementation. Furthermore, the programs' effective impacts were assumed to lag behind implementation by one or two years. All of these aforementioned factors were included as independent variables in the model.

The fixed-effects model was formulated as described in Equation (1):

$$
\begin{aligned}
N D V I_{i t}= & \beta_{1} \text { prec }_{i t}+\beta_{2} \text { pop }_{i t}+\beta_{3} \ln g d p_{i t}+\beta_{4} \text { farm }_{i t}+\beta_{5} \text { BTWSSC }_{i(t-1)}, \\
& +\beta_{6} \text { BTWSSC }_{i(t-2)}+\beta_{7} \operatorname{ESAS}_{i(t-1)}+\beta_{8} \operatorname{ESAS}_{i(t-2)}+a_{i}+\mu_{i t}
\end{aligned}
$$

where $i$ denotes the 12 counties, and $t$ denotes the years from 1998 to 2013. NDVI $I_{i t}$ is the mean of all pixels' NDVI values in county $i$ at year $t$; $\operatorname{prec}_{i t}$ is county $i$ 's annual precipitation (mm) at year $t$; pop $p_{i t}$ denotes the human population density, which is county $i$ 's population (person) at year $t$ divided by its land area $\left(\mathrm{km}^{2}\right) ; g d p_{i t}$ denotes the economic activity intensity, which is county $i$ 's gross domestic production (thousand Yuan) at year $t$ divided by its land area $\left(\mathrm{km}^{2}\right)$, adjusted by Inner Mongolia's consumer price index using 1998 as a base year and transformed logarithmically in the model; farm it denotes the crop farming intensity, which is a county's grain output (metric tonnes) divided by its land area $\left(\mathrm{km}^{2}\right) ; B T W S S C$ and ESAS are two dummy variables, which were assigned a value of 1 when a specific program was implemented, otherwise 0 . The subscripts of $t-1$ and $t-2$ on BTWSSC and $E S A S$ indicate that program impacts were delayed for one year or two years, respectively.

In Equation (1), $a_{i}$ is the fixed effect of county $i$, which represents all unobserved factors affecting county $i$ 's NDVI value that do not change over time. Likewise, $\mu_{i t}$ denotes the idiosyncratic error or time-varying error, and represents unobserved factors that affect $N D V I_{i t}$ and change over time. All variable definitions and their basic statistics are summarized in Table 1.

\begin{tabular}{|c|c|c|c|c|}
\hline Variables & Definition & Unit & Mean & $\begin{array}{l}\text { Standard } \\
\text { Deviation }\end{array}$ \\
\hline$N D V I_{i t}$ & Mean of all cells' NDVI values in county $i$ at year $t$ & na & 0.3838 & 0.1314 \\
\hline prec $_{i t}$ & Annual precipitation of county $i$ at year $t$ & $\mathrm{~mm}$ & 256.67 & 90.64 \\
\hline pop $p_{i t}$ & $\begin{array}{l}\text { Human population of county } i \text { at year } t \text { divided by its } \\
\text { land area }\end{array}$ & person $\mathrm{km}^{-2}$ & 11.56 & 16.39 \\
\hline $\ln g d p_{i t}$ & $\begin{array}{l}\text { Logarithmically transformed gross domestic production } \\
\text { of county } i \text { at year } t \text { divided by its land area }\end{array}$ & $\begin{array}{l}\text { thousand } \\
\text { Yuan } \cdot \mathrm{km}^{-2}\end{array}$ & 4.651 & 1.304 \\
\hline farm $_{i t}$ & $\begin{array}{l}\text { Grain output of county } i \text { at year } t \text { divided by its } \\
\text { land area }\end{array}$ & tonnes $\mathrm{km}^{-2}$ & 3.792 & 9.879 \\
\hline BTWSSC $_{i(t-1)}$ & $\begin{array}{l}\text { Dummy variable, } 1 \text {-year delayed effect of the BTWSSC } \\
\text { program on NDVI value of county } i \text { at year } t\end{array}$ & na & na & na \\
\hline BTWSSC $_{i(t-2)}$ & $\begin{array}{l}\text { Dummy variable, 2-year delayed effect of the BTWSSC } \\
\text { program on NDVI value of county } i \text { at year } t\end{array}$ & na & na & na \\
\hline$E S A S_{i(t-1)}$ & $\begin{array}{l}\text { Dummy variable, 1-year delayed effect of the ESAS } \\
\text { program on NDVI value of county } i \text { at year } t\end{array}$ & na & na & na \\
\hline$E S A S_{i(t-2)}$ & $\begin{array}{l}\text { Dummy variable, 2-year delayed effect of the ESAS } \\
\text { program on NDVI value of county } i \text { at year } t\end{array}$ & na & na & na \\
\hline
\end{tabular}

Table 1. Variable definitions for the fixed-effects model and basic statistics.

NDVI: Normalized difference vegetation index; BTWSSC: Beijing-Tianjin Wind/Sand Source Control; ESAS:

Ecological Subsidy and Award System; na = not applicable.

A fixed-effects transformation was applied to eliminate $a_{i}$ [49], yielding a general time-demeaned model as Equation (2):

$$
N D V I_{i t}^{\prime}=\beta_{1} \operatorname{prec}_{i t}^{\prime}+\beta_{2} g r a z_{i t}^{\prime}+\beta_{3} p o p_{i t}^{\prime}+\beta_{4} \ln g d p_{i t}^{\prime}+\beta_{5} f a r m_{i t}^{\prime}+\mu_{i t}^{\prime},
$$

in which we estimated using the pooled Ordinary Least Square method. In Equation (2), $N D V I_{i t}^{\prime}=N D V I_{i t}-\overline{N D V I}_{i}$, and similarly for all explanatory variables and $\mu_{i t}^{\prime}$. 
We separately applied the fixed-effects model defined by Equation (2) to the group of nine pastoral counties and to the group of three non-pastoral counties, as well as to all counties, collectively. Given that the grassland use pattern in the semi-pastoral county of Taibus was significantly different from that in pastoral counties, we included Taibus in the group of non-pastoral counties.

\subsection{Data Acquisition and Processing}

We used 16 years (1998 to 2013, inclusive) of panel data for all 12 counties of Xilingol League, yielding 192 observations.

The NDVI data were retrieved from the SPOT-VEGETATION NDVI data products (Flemish Institute for Technological Research, Vito, Belgium). The data record began in April 1998, at a spatial resolution of $1 \mathrm{~km}$ and a temporal resolution of 10 days. Because the original measurements were stored as byte data type (0-255), the data were transformed into NDVI values $(-1,1)$ using the "band" mathematical function in the software ENVI 4.8 (Harris Geospatial Solutions, Broomfield, CO, USA). For this study, only the NDVI values at the end of August were used, which is the time grassland grows most vigorously. Then, the mean of NDVI values of all pixels in each county each year was calculated.

Annual precipitation data were retrieved from the Chinese National Meteorological Information Center [50]. There are 47 meteorological stations in Inner Mongolia. The Kriging method was used to interpolate the annual precipitation values for each pixel in Xilingol League, from which the mean value in each county for each year was determined.

The data describing human population, gross domestic product, grain output and total land area of each county were retrieved from the Statistical Year Book of Inner Mongolia (1999-2014). The implementation durations and ranges of the BTWSSC program and ESAS program were identified by reviewing relevant policy documents from the State Council and Inner Mongolia, and confirmed by the Bureau of Agriculture and Animal Husbandry in Xilingol League.

\subsection{Data Analysis}

The STATA 12.0 software package (StataCorp LP, College Station, TX, USA) was used to estimate the parameters in the fixed-effects model. ENVI 4.8 was used to calculate the NDVI differences between 1998 and 2000, 2000 and 2010, 2010 and 2013, and 2000 and 2013. ArcGIS 10.2 (Environmental Systems Research Institute, Inc., Redlands, CA, USA) was used for interpolations of annual precipitation, spatial statistical analysis and mapping.

\section{Results}

\subsection{Spatial and Temporal Variations of Vegetation Coverage in Xilingol League from 1998 to 2013}

As shown in Figure 4A, before the implementation of major grassland conservation programs (i.e., from 1998 to 2000), the changes in vegetation coverage indicated by NDVI differences of all pixels in Xilingol League demonstrated a general trend of degradation. In this period, $94.5 \%$ of grasslands were degraded to some extent; $9.14 \%$ were relatively severely degraded and NDVI values decreased by more than 0.3 . Areas of severe grassland degradation were concentrated in the northeastern part of the League, including Xilinhot, East Ujimqin, West Ujimqin and Abag, all of which are pastoral counties. In the same period, only $5.5 \%$ of grassland vegetation improved.

Following implementation of the BTWSSC program in 2001 and the ESAS program in 2013, the grassland vegetation status showed a general trend of improvement. From 2000 to 2013, 74.8\% of grasslands were improved and only $25.2 \%$ were degraded. The major areas of degradation were concentrated in the northern and western part of the League, especially in East Ujimqin, West Ujimqin, Sonid Left, Sonid Right, and Abag, all of which are pastoral counties (Figure 4B). 

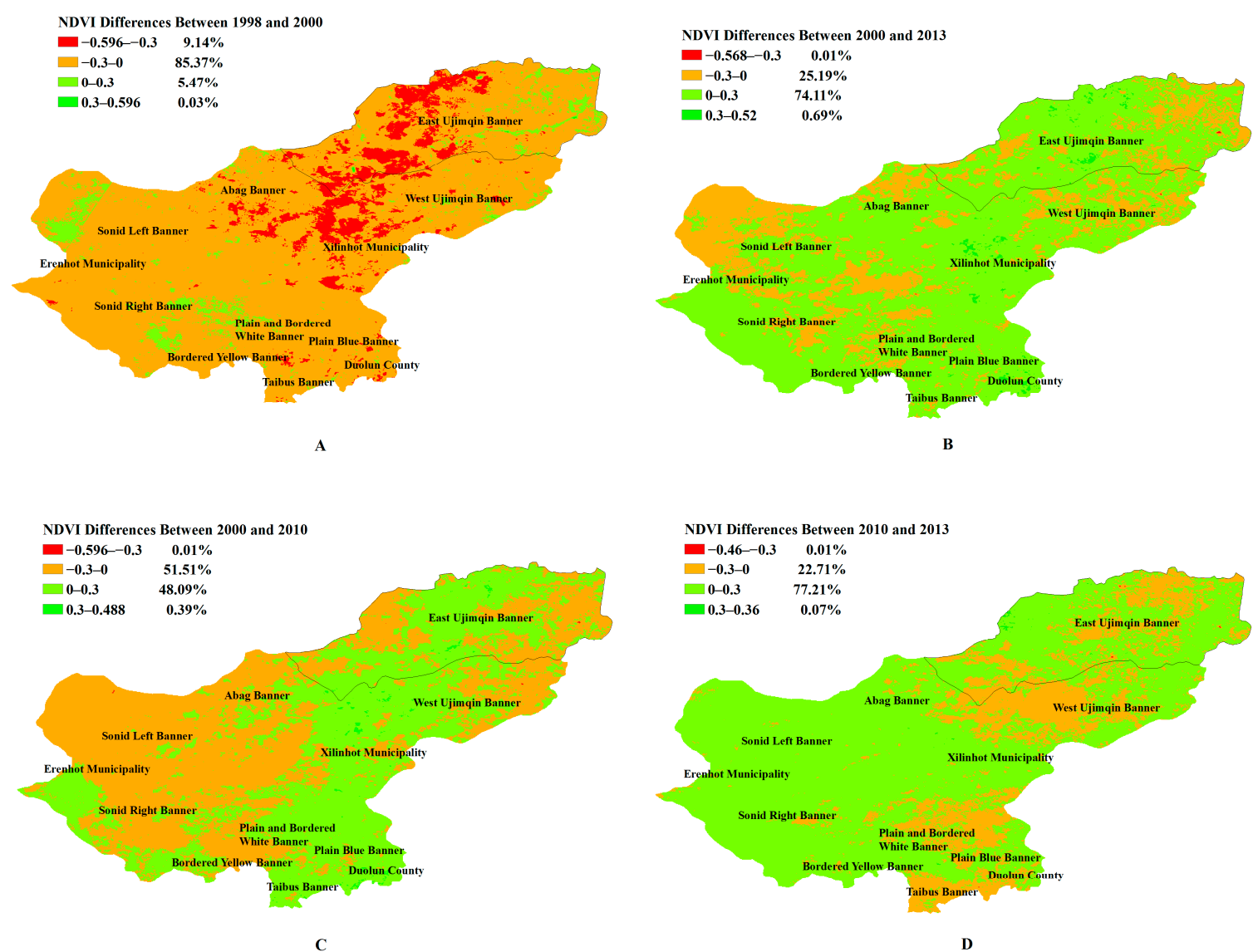

Figure 4. Differences in the net difference vegetation index (NDVI) of Xilingol League between (A) 1998 and 2000; (B) 2000 and 2013; (C) 2000 and 2010; and (D) 2010 and 2013.

However, by comparing the vegetation changes of 2000-2010 (after the introduction of the BTWSSC program) with those of 2010-2013 (after the introduction of the ESAS program), a more obvious improvement was found in the latter. During 2000-2010, 48.5\% of grasslands were improved and $51.5 \%$ were degraded, and the areas of major degradation were concentrated in the northern and western part of the League, especially in East Ujimqin, West Ujimqin, Sonid Left, Sonid Right, Abag, Bordered Yellow, Plain and Bordered White, all of which are pastoral counties (Figure 4C). During 2010-2013, 77.3\% of grasslands were improved and $22.7 \%$ were degraded and, surprisingly, the areas of major degradation were concentrated in the eastern part of the League, including East Ujimqin, West Ujimqin, Plain Blue, Duolun and Taibus. The latter two of these counties are non-pastoral counties (Figure 4D).

Although grassland vegetation conditions as a whole were generally improved since 2000, the improvements may have been caused by other factors, such as variation in precipitation. The possible influence of other factors was examined and is described in Section 3.2.

\subsection{Contributors to NDVI Value Changes in Xilingol League from 1998 to 2013}

Estimates for the parameters in the three fixed-effects models and their significance levels are summarized in Table 2.

In the model for the group of pastoral counties, annual precipitation, $B T W S S C_{t-2}, E S A S_{t-2}$ and fixed effects significantly $(p<0.01)$ and positively impacted the county's mean NDVI value. In these pastoral counties, $100 \mathrm{~mm}$ additional annual precipitation is predicted to increase the mean NDVI value by 0.059 . Although the implementation of both BTWSSC and ESAS programs did not immediately and significantly play a role in restoring grassland vegetation, these positive impacts began to emerge after 
two years. Enrolling in the BTWSSC program or ESAS program at a specific year was predicted to increase the NDVI value by 0.085 or 0.054 , respectively, after two years. These levels of improvement are equivalent to those produced by $143 \mathrm{~mm}$ and $91 \mathrm{~mm}$ of additional annual precipitation, respectively $(p<0.01)$. The parameter estimate of fixed effects was approximately 0.238 , remarkably higher than those of other independent variables.

Table 2. Estimates of parameter values and their significance levels for the three fixed-effects models.

\begin{tabular}{|c|c|c|c|}
\hline \multicolumn{4}{|c|}{ Dependent Variable: $N D V I_{t}$} \\
\hline Independent Variables & Pastoral Counties & Non-Pastoral Counties & All Counties \\
\hline \multirow{2}{*}{ prect $_{t}$} & $0.000593^{* * *}$ & 0.000346 & $0.000496^{* * *}$ \\
\hline & $(0.000098)$ & $(0.000208)$ & $(0.000105)$ \\
\hline \multirow{2}{*}{ popt } & 0.010828 * & -0.008827 & $0.011678^{* *}$ \\
\hline & $(0.004950)$ & $(0.013012)$ & $(0.003982)$ \\
\hline \multirow{2}{*}{$\ln g d p_{t}$} & $-0.028087^{* *}$ & 0.011959 & $-0.025898^{* * *}$ \\
\hline & $(0.008491)$ & $(0.027944)$ & $(0.007323)$ \\
\hline \multirow{2}{*}{ farm $_{t}$} & 0.001617 & 0.000004 & -0.000355 \\
\hline & $(0.005232)$ & $(0.000193)$ & $(0.000217)$ \\
\hline \multirow{2}{*}{ BTWSSC $_{t-1}$} & -0.015598 & -0.055948 & $-0.021886^{*}$ \\
\hline & $(0.011848)$ & $(0.050088)$ & $(0.011235)$ \\
\hline \multirow{2}{*}{$E S A S_{t-1}$} & 0.030130 & 0.008291 & $0.038136^{* *}$ \\
\hline & $(0.019851)$ & $(0.037597)$ & $(0.016597)$ \\
\hline \multirow{2}{*}{ BTWSSC $_{t-2}$} & $0.085061^{* * *}$ & $0.095782 * *$ & $0.092436^{* * *}$ \\
\hline & $(0.014685)$ & $(0.022237)$ & $(0.013894)$ \\
\hline \multirow{2}{*}{$E S A S_{t-2}$} & $0.054234^{* * *}$ & 0.037332 & $0.048633^{* * *}$ \\
\hline & $(0.007897)$ & $(0.023596)$ & $(0.007053)$ \\
\hline \multirow[t]{2}{*}{ constant } & $0.237703^{* * *}$ & 0.473286 & $0.185076^{* * *}$ \\
\hline & $(0.031152)$ & $(0.324697)$ & $(0.042854)$ \\
\hline Adjusted $R^{2}$ & 0.576 & 0.398 & 0.540 \\
\hline $\mathrm{F}$ & 811.25 & 5 & 127.285 \\
\hline$N$ & 126 & 42 & 168 \\
\hline
\end{tabular}

Standard errors in parentheses; ${ }^{*} p<0.10,{ }^{* *} p<0.05,{ }^{* * *} p<0.01$.

As expected, economic intensity also significantly $(p<0.05)$ and negatively affected grassland vegetation in pastoral counties, and a $1 \%$ higher of gross domestic product was predicted to decrease the NDVI value by 0.00028 . Given the rapid economic growth of the study area in recent decades (growth by 10 times from 1998 to 2013 in real terms), economic development is a non-negligible force in the degradation of grassland vegetation. Surprisingly, population growth was shown to play a marginally significant $(p<0.10)$ but positive role in improving grassland vegetation, which contradicts the findings of most previous studies.

In the model for non-pastoral counties, only $B T W S S C_{t-2}$ had a significant impact on NDVI value $(p<0.05)$, and enrolling in the BTWSSC program at a specific year was predicted to increase the NDVI value by 0.096 after two years. Other factors had no significant impact on NVDI, maybe due to a lack of observations in this group for three counties and the relatively complex variations among the counties, one of which was semi-pastoral, one was dominated by crop-farming, and one was an urban district.

In the model applied to all counties collectively, the explanatory variables' impacts and their significance levels were similar to those in the model of the pastoral counties. Annual precipitation, $B T W S S C_{t-2}, E S A S_{t-2}$ and fixed effects had significant and positive impacts on NDVI values. Enrolling in the BTWSSC program or ESAS program at a specific year was predicted to increase the NDVI value by 0.092 or 0.049 , respectively, after two years. These levels of improvement were equivalent to those produced by $186 \mathrm{~mm}$ and $98 \mathrm{~mm}$ increased annual precipitation, respectively $(p<0.01)$. Economic intensity had a negative impact on NDVI, but the level of significance $(p<0.01)$ was higher than that in the model of pastoral counties alone $(p<0.05)$, and population growth also had a significant but positive impact $(p<0.05)$. Moreover, the effect of obtaining a grant from both BTWSSC 
and ESAS programs was predicted to occur earlier by the model of all counties than by the model of only pastoral counties. After one year of implementation, the predicted NDVI value increased by 0.038 for the ESAS program $(p<0.05)$, but decreased by 0.022 for the BTWSSC program; however, the latter impact was marginally significant $(p<0.10)$.

\section{Discussion}

\subsection{Effects of Major Grassland Conservation Programs on Vegetation Restoration}

Temporal analysis of vegetation changes in Xilingol League suggested that, before the introduction of major grassland conservation programs, the vegetation coverage demonstrated a general trend of degradation. However, after the introduction of two programs (BTWSSC and ESAS), the grassland vegetation showed a general trend of improvement. In addition, a more obvious improvement was found between 2010 and 2013 than prior to 2010 (the ESAS program was introduced in 2011). An econometric model analysis further confirmed these findings. Both BTWSSC and ESAS programs had positive and significant impacts on the recovery of grassland vegetation, especially in the pastoral regions and after two years of implementation. These benefits were apparent in the model results after controlling for other factors' impacts and the unobserved, time-constant effects embodied in $a_{i}$. The ESAS program was also shown to have positive effects after only one year of implementation, while the impacts of the BTWSSC program were negative after one year of implementation. This difference may be attributed to a significantly higher subsidy level in the ESAS program than in the BTWSSC program. Spatial analysis of vegetation changes in Xilingol League showed that areas of major vegetation degradation during the study period were concentrated in the pastoral counties, especially in the northern and western part of the League. This may be due to the relatively drier climate condition of these areas, or to the extensive animal husbandry production pattern in the pastoral counties.

Overall, both the spatial-temporal analysis and the econometric model analysis suggested that the grassland conservation programs had a positive effect on grassland vegetation rehabilitation. This finding is consistent with the majority of previous studies. In a literature review, $\mathrm{Li}$ and $\mathrm{Li}$ [51] found that $72 \%$ of previous studies since 2002 indicated that rangeland ecological construction programs led to effective protection and restoration of rangelands. Managing grazing intensity works better than selective grazing, and compensatory growth may be weakly linked to ecosystem processes in arid grasslands [52]. Our study further contributes to this research field by finding that the positive effect of the conservation programs lagged implementation by 1-2 years.

\subsection{Natural and Anthropogenic Disturbances to the Success of Grassland Conservation Programs}

Our econometric modeling indicated that annual precipitation plays a significant and positive effect on grassland vegetation growth in the pastoral region. A climate change study by Li et al. [15] suggested that the climatic trend in Xiligol will be toward a warmer and drier climate, and the northwestern part will be much cooler and drier than the southeastern part. This difference in climate change intensity may explain why most degradation during the study period appeared in the northern and western parts (Figure 4). Future climatic drying constitutes a great threat to the success of grassland conservation programs $[53,54]$.

Moreover, rapid economic growth can also be a detriment to the success of grassland conservation programs. According to the Statistical Year Book of Inner Mongolia, the real gross domestic product grew by 11.05 times from 1998 to 2013 (from 5.6 billion Yuan to 62.2 billion Yuan, using 1998 as a base year). As suggested by our model for all counties, a $1 \%$ higher gross domestic product was predicted to decrease the NDVI value by 0.00025898 , indicating that this growth would reduce the mean NDVI value by approximately 0.2862 . Thus, economic growth exerted a greater influence on NDVI than did implementation of grassland conservation programs. The pace of the recent rapid economic growth in Xilingol League will not slow down in the short term. In recent years, the scales of coal mining, metallurgy, chemical production and power generation have grown quickly in Xilingol 
League. For example, coal output increased to 141 million tonnes in 2013, and extensive raw material mining exerted continually higher pressure on grassland vegetation. To maintain the achievements of the grassland conservation programs, it is necessary for the League to abandon the extensive production pattern of mineral exploitation, and to adopt more intensive, more environmentally friendly techniques, while developing more technology-intensive and more water-efficient industries, such as grassland ecotourism.

Most previous studies have been based on the premise that higher human population density could result in grassland vegetation degradation in the arid environment of Inner Mongolia [55]. However, in the current study, the parameter estimates of population density were positive in the models of pastoral counties as well as of all counties. This unexpected result may be attributed to recent government policy promoting herders' sedentary living and concentrated settlement, which helps to mitigate the anthropogenic pressures on the vast grasslands of Xilingol League. According to a survey on human migration in the pastoral region of Xilingol League, ecological emigration began in 2002 , and a total of 42,572 persons from 9227 households emigrated out of the enclosed grassland areas, including 37,172 persons from 7927 herding households. As a result, 93 concentrated resettlement sites were established to host 32,886 persons from 7336 households. However, due to difficulties in speaking Chinese, adapting to a non-pastoral lifestyle and securing a livelihood in towns, population backflow was a normal phenomenon. Since the initiation of ecological emigration, the human populations of both agricultural and pastoral regions in Inner Mongolia have decreased remarkably. The population of pastoral regions decreased from 1.93 million in 2000 to 1.49 million in 2009; however, the population rose to 1.81 million in 2013 due to the backflow of herdsmen [56]. Furthermore, a quadratic equation $\left(R^{2}=0.8077\right)$ was much better than a linear relationship $\left(R^{2}=0.2608\right)$ for describing the population trend in pastoral regions (Figure 5). During the same period, the population of all Inner Mongolia increased from 23.09 million in 2000 to 25.24 million in 2013. Hence, the majority of population growth occurred in towns, and citizens worked in the industrial and service sectors without exerting pressure on grassland. In fact, population declines in pastoral regions mitigated the damage to grassland vegetation.

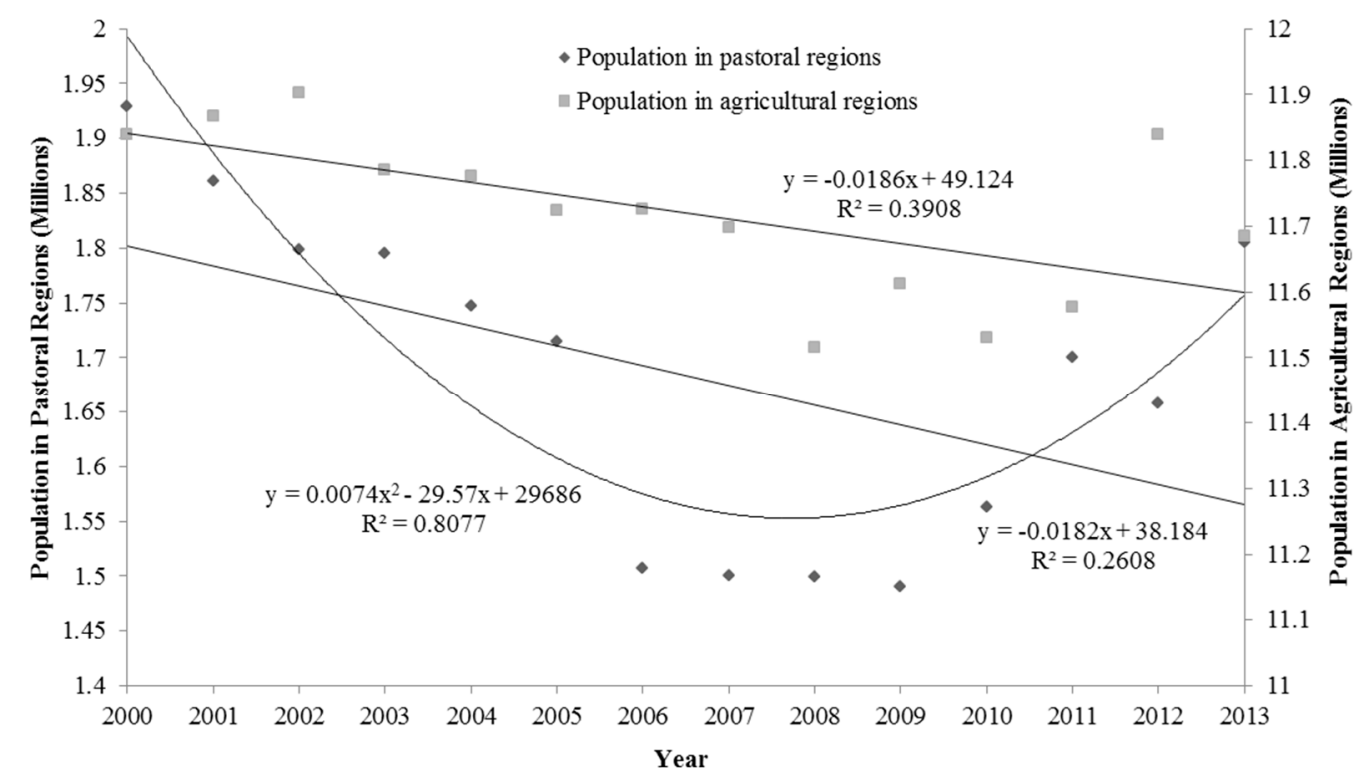

Figure 5. Human population trend of the pastoral and agricultural regions of Inner Mongolia. Data source: Statistical Yearbook of Inner Mongolia (2000-2014).

The fixed effects were remarkably higher than those of other impactors, as our modeling results suggested, indicating that the time-constant unobserved factors played a major role in grassland 
vegetation condition; these fixed-effect factors included the geomorphological characteristics (elevation, slope aspect and slope gradient, etc.) and the historical determinants of grassland use. This finding has an important meaning for the design and implementation of conservation programs. Although human intervention by engineering and economic instruments could assist the restoration of natural grassland, the underlying logic and philosophy should be from an ecological viewpoint, and the design and implementation of programs should follow the basic characteristics and rules of grassland ecosystem succession in specific context. For instance, based on an evaluation of key driving forces of desertification and rehabilitation from the 1950s to the early 2000s in the Otindag Sandland, which is part of Xilingol grassland, Wang et al. [57] concluded that previous studies might have overestimated the impact of human activities, and that, on the contrary, climatic factors had a much stronger effect than previously acknowledged. In arid grazing lands of central Australia, Friedel et al. [58] also found herbage biomass, cover and composition responded primarily to these geomorphic strata and not to grazing. In degraded high mountain grazing lands of northern Ethiopia, Asefa et al. [59] found site factors in general had a greater effect on diversity of plant life forms than management types and time length of enclosure.

\section{Conclusions}

Using vegetation and socio-economic data from 1998 to 2013 for Xilingol League, Inner Mongolia, we examined the long-term and regional-scale effects of two major grassland conservation programs, namely the BTWSSC and ESAS programs. Generally speaking, grassland conservation programs exerted a positive effect on grassland vegetation rehabilitation, therein our study verified the effectiveness of grazing pressure relief on a regional scale in this specific region. Hence, the grassland conservation programs should continue with increased investment in the future, while focusing on severely degraded regions and encouraging more intensive animal husbandry production techniques, such as confined livestock production. A time lag was found between when farmers enrolled in the conservation programs and when a vegetation rehabilitation effect was generated. In general, enrolling in the BTWSSC and ESAS programs improved the grassland vegetation condition of a county after a lag of two years. Thus, when conducting a performance evaluation and money transfer, program supervisors should not expect positive vegetation changes in the first two years. A caution is warranted, however. As our modeling results suggested, the time-constant unobserved factors including site factors and land use history had a greater effect on arid grassland vegetation conditions; therefore, the design and implementation of government conservation policies should follow the basic characteristics and rules of grassland ecosystem succession and be context-based.

Rapid and extensive mineral exploitation could partially or completely offset the positive effects of the conservation programs on grassland vegetation rehabilitation, and a transition of the current economic development pattern into more water-efficient and technology-intensive industries should be promoted. Herdsmen emigration and concentrated resettlement helps to lessen the impacts of human activities on grassland; however, vocational education and training is necessary to build a stronger capacity of herdsmen to adapt to urban life and minimize population backflows. Future climate drying also constitutes a major threat to the achievements of conservation efforts, especially when the conservation programs target the pastoral regions of northern and western parts of Xilingol League, which will be drier than the southeastern part in the future.

Relatively short-term effects of the ESAS program, which began only in 2011, were examined in this study, so the long-term effects need to be further monitored. Further studies should also focus on setting appropriate compensation levels for herders' conservation behaviors; in this respect, ecosystem service valuation can play a vital role and contribute to determining the positive externality value of grassland conservation. In addition, our study neglects the spatial spillover effects of program areas on non-program areas, a phenomenon criticized by many scholars when evaluating similar conservation programs. To address spillover effects, spatial econometric models could be applied. The effects of grassland conservation programs on herders' livelihoods and community culture should also be 
studied further; in this respect, an ecosystem service tradeoff analysis could contribute to improved policy and help achieve a goal of multi-objective synergy.

Acknowledgments: We thank two anonymous reviewers for their constructive comments on an earlier version of the paper. This work was supported by MOE (Ministry of Education in China), Projects of Humanities and Social Sciences (Project No. 16YJC630003 and No. 16YJC790085), and the National Natural Science Fund of China (Grant No. 71603207 and No. 71573211).

Author Contributions: Liqun Shao and Xuexi Huo conceived and designed the research; Haibin Chen and Chen Zhang collected and analyzed the data; Liqun Shao wrote the paper; and Xuexi Huo and Liqun Shao proofread, edited and revised the paper.

Conflicts of Interest: The authors declare no conflict of interest.

\section{References}

1. US Department of Agriculture, Soil Conservation Service. National Range Handbook; US Department of Agriculture: Washington, DC, USA, 1976.

2. Branson, F.A.; Gifford, G.F.; Renard, K.G.; Hadley, R.F. Rangeland Hydrology. Society for Range Management Range Science Series No. 1; Kendall: Dubuque, IA, USA, 1981.

3. Allen-Diaz, B.; Chapin, F.S.; Diaz, S.; Howden, M.; Puigdefábregas, J.; Stafford Smith, M. Rangelands in a changing climate: Impacts, adaptations, and mitigation. In Climate Change 1995: Impacts, Adaptations and Mitigation of Climate Change: Scientific-Technical Analyses; Cambridge University Press: Cambridge, UK, 1995; pp. 131-158.

4. Havstad, K.M.; Peters, D.P.; Skaggs, R.; Brown, J.; Bestelmeyer, B.; Fredrickson, E.; Herrick, J.; Wright, J. Ecological services to and from rangelands of the United States. Ecol. Econ. 2007, 64, 261-268. [CrossRef]

5. Twidwell, D.; Allred, B.W.; Fuhlendorf, S.D. National-scale assessment of ecological content in the world's largest land management framework. Ecosphere 2013, 4, 1-27. [CrossRef]

6. Miller, M.E.; Belote, R.T.; Bowker, M.A.; Garman, S.L. Alternative states of a semiarid grassland ecosystem: Implications for ecosystem services. Ecosphere 2011, 2, 1-18. [CrossRef]

7. Kéfi, S.; Rietkerk, M.; Alados, C.L.; Pueyo, Y.; Papanastasis, V.P.; ElAich, A.; De Ruiter, P.C. Spatial vegetation patterns and imminent desertification in Mediterranean arid ecosystems. Nature 2007, 449, 213-217. [CrossRef] [PubMed]

8. Milton, S.J.; du Plessis, M.A.; Siegfried, W.R. A conceptual model of arid rangeland degradation. Bioscience 1994, 44, 70-76. [CrossRef]

9. Daliakopoulos, I.N.; Tsanis, I.K. Climate-induced catastrophic shifts in pastoralism systems managed under the maximum sustainable yield model. Oper. Res. 2014, 14, 177-188. [CrossRef]

10. Porensky, L.M.; Mueller, K.E.; Augustine, D.J.; Derner, J.D. Thresholds and gradients in a semi-arid grassland: Long-term grazing treatments induce slow, continuous and reversible vegetation change. J. Appl. Ecol. 2016, 53, 1013-1022. [CrossRef]

11. Van de Koppel, J.; Rietkerk, M.; Weissing, F.J. Catastrophic vegetation shifts and soil degradation in terrestrial grazing systems. Trends Ecol. Evol. 1997, 12, 352-356. [CrossRef]

12. Ellis, J. Grasslands and Grassland Sciences in Northern China; National Academies: Washington, DC, USA, 1992.

13. Waldron, S.; Brown, C.; Longworth, J. Grassland degradation and livelihoods in China's western pastoral region: A framework for understanding and refining China's recent policy responses. China Agric. Econ. Rev. 2010, 2, 298-320. [CrossRef]

14. Han, J.; Zhang, Y.; Wang, C.; Bai, W.; Wang, Y.; Han, G.; Li, L. Rangeland degradation and restoration management in China. Rangel. J. 2008, 30, 233-239. [CrossRef]

15. Li, S.; Verburg, P.H.; Lv, S.; Wu, J.; Li, X. Spatial analysis of the driving factors of grassland degradation under conditions of climate change and intensive use in Inner Mongolia, China. Reg. Environ. Chang. 2011, 12, 461-474. [CrossRef]

16. Chen, H.; He, L.; Tang, H.; Zhao, M.; Shao, L. A Two-Step Strategy for Developing Cultivated Pastures in China that Offer the Advantages of Ecosystem Services. Sustainability 2016, 8, 392. [CrossRef]

17. Akiyama, T.; Kawamura, K. Grassland degradation in China: Methods of monitoring, management and restoration. Grassl. Sci. 2007, 53, 1-17. [CrossRef] 
18. Jiang, G.; Han, X.; Wu, J. Restoration and management of the Inner Mongolia grassland require a sustainable strategy. Ambio 2006, 35, 269. [CrossRef] [PubMed]

19. Sheng, G.; Harazono, Y.; Oikawa, T.; Zhao, H.; Zong, Y.; Xue, L. Grassland desertification by grazing and the resulting micrometeorological changes in Inner Mongolia. Agric. For. Meteorol. 2000, 102, 125-137.

20. Yang, Y.; Fang, J.; Ma, W.; Smith, P.; Mohammat, A.; Wang, S.; Wei, W. Soil carbon stock and its changes in northern China's grasslands from 1980s to 2000s. Glob. Chang. Biol. 2010, 16, 3036-3047. [CrossRef]

21. Aronson, J.; Floret, C.; Floc'h, E.; Ovalle, C.; Pontanier, R. Restoration and rehabilitation of degraded ecosystems in arid and semi-arid lands. I. A View from the South. Restor. Ecol. 1993, 1, 8-17. [CrossRef]

22. Li, W.; Li, Y. Rangeland Degradation Control in China: A Policy Review. In The End of Desertification? Springer: Berlin/Heidelberg, Germany, 2016; pp. 491-511.

23. Chen, J.; Tang, H. Effect of Grazing Exclusion on Vegatation Characteristics and Soil Organic Carbon of Leymus chinensis Grassland in Northern China. Sustainability 2016, 8, 56. [CrossRef]

24. Zhang, X.; Niu, J.; Buyantuen, A.; Zhang, Q.; Dong, J.; Kang, S.; Zhang, J. Understanding Granssland Degrandation and Restoration from the Perspective of Ecosystem Services: A Case Study of the Xilin River Basin in Inner Monglia, China. Sustainability 2016, 8, 594. [CrossRef]

25. Liu, A.; Xing, Q.; Su, R.; Wang, J.; Guo, G. Study on Effects of Grassland Bans and Rests in Xilingol League. Inner Mong. Prataculture 2003, 15, 1-4. (In Chinese)

26. Shi, S.; Zou, X.; Zhang, C.; Su, G. Investigation of vegetation restoration in the area of Beijing and Tianjin sandstorm source control project. Sci. Soil Water Conserv. 2009, 7, 86-92. (In Chinese)

27. Xing, Q.; Liu, A.; Liu, Y.; Gao, W. Study on Change of Rangeland Vegetation Using MODIS-NDVI in Xilingol Grassland. Acta Agrestia Sin. 2005, 13, 15-19. (In Chinese)

28. Wang, L. Some thoughts on the performance and sustainability of retire livestock restore grassland projects. J. Inner Mong. Agric. Univ. 2009, 11, 116-118. (In Chinese)

29. Wang, Y.; Qiao, Y. Problems in implementing retire livestock, restore grassland projects and counter measures. Agric. Econ. Probl. 2011, 2, 99-103. (In Chinese)

30. Gu, Y.; Li, W. Research on the grazing ban policy's effect to grassland quality: Analysis on the scale of herdersman households. Acta Sci. Nat. Univ. Pekinensis 2013, 49, 288-296. (In Chinese)

31. McNaughton, S. Grazing as an optimization process: Grass-ungulate relationships in the Serengeti. Am. Nat. 1979, 113, 691-703. [CrossRef]

32. Rui, X.; Shuia, Z.; YongFei, B. Impacts of grazing intensity and management regimes on aboveground primary productivity and compensatory growth of grassland ecosystems in Inner Mongolia. Biodivers. Sci. 2010, 18, 300-311. [CrossRef]

33. DeAngelis, D.L.; Waterhouse, J.C. Equilibrium and nonequilibrium concepts in ecological models. Ecol. Monogr. 1987, 57, 1-21. [CrossRef]

34. Pickup, G.; Bastin, G.N.; Chewings, V.H. Identifying trends in land degradation in non-equilibrium rangelands. J. Appl. Ecol. 1998, 35, 365-377. [CrossRef]

35. Pickup, G. Estimating the effects of land degradation and rainfall variation on productivity in rangelands: An approach using remote sensing and models of grazing and herbage dynamics. J. Appl. Ecol. 1996, 33, 819-832. [CrossRef]

36. Tongway, D.J.; Sparrow, A.D.; Friedel, A. Degradation and recovery processes in arid grazing lands of central Australia. Part 1: Soil and land resources. J. Arid Environ. 2003, 55, 301-326. [CrossRef]

37. Carlson, T.N.; Ripley, D.A. On the relation between NDVI, fractional vegetation cover, and leaf area index. Remote Sens. Environ. 1997, 62, 241-252. [CrossRef]

38. Karnieli, A.; Agam, N.; Pinker, R.T.; Anderson, M.; Imhoff, M.L.; Gutman, G.G.; Panov, N.; Goldberg, A. Use of NDVI and land surface temperature for drought assessment: Merits and limitations. J. Clim. 2010, 23, 618-633. [CrossRef]

39. Gong, Z.; Kawamura, K.; Ishikawa, N.; Goto, M.; Wulan, T.; Alateng, D.; Yin, T.; Ito, Y. MODIS normalized difference vegetation index (NDVI) and vegetation phenology dynamics in the Inner Mongolia grassland. Solid Earth 2015, 6, 1185-1194. [CrossRef]

40. Tong, C.; Wu, J.; Yong, S.; Yang, J.; Yong, W. A landscape-scale assessment of steppe degradation in the Xilin River Basin, Inner Mongolia, China. J. Arid Environ. 2004, 59, 133-149. [CrossRef]

41. Liu, S.; Yan, D.H.; Shi, X.L.; Wang, G.; Yuan, Z.; Yin, J. Grassland NDVI response to climate factors in different vegetation regionalizations in China. Commun. Comput. Inf. Sci. 2013, 399, 370-380. 
42. Verbeek, M. A Guide to Modern Econometrics; John Wiley \& Sons: Hoboken, NJ, USA, 2008.

43. Wang, X.; Han, J.; Dong, Y. Recent grassland policies in China: An overview. Outlook Agric. 2005, 34, $105-110$. [CrossRef]

44. Grassland Supervision and Management Bureau, Inner Mongolia Autonomous Region. Annual Monitoring Report on Ecological Effects of Grazing Withdrawal Project (2011). Hohhot, China, 2012. Available online: http:/ / www.nmagri.gov.cn/zxq/bmdt/219606.shtml (accessed on 2 September 2016). (In Chinese)

45. National Development and Reform Commission, The State Council, P.R.C. Beijing-Tianjin Wind/Sand Source Control Project Plan (2001-2010). Beijing, China, 2002. Available online: http:/ /www.sdpc.gov.cn/fzgggz/ ncjj/nczc/200804/t20080414_203913.html (accessed on 2 September 2016). (In Chinese)

46. National Development and Reform Commission, The State Council, P.R.C. Beijing-Tianjin Wind/Sand Source Control Project Stage II Plan (2013-2022). Beijing, China, 2012. Available online: http:/ /www.gov.cn/jrzg/ 2012-10/07/content_2238717.htm (accessed on 2 September 2016). (In Chinese)

47. Miao, D.; Liu, Y. Annual National Grassland Monitoring Report (2012). Chin. Anim. Husb. 2013, 8, 14-29. (In Chinese)

48. Department of Agriculture and Animal Husbandry, Inner Mongolia Autonomous Region. Implementatino Plan for Grassland Ecological Subsidy and Award System. Hohhot, China, 2011. Available online: http://www.nmgzfgb.gov.cn/information/nmgzb20/msg6770100299.html (accessed on 2 September 2016). (In Chinese)

49. Wooldridge, J.M. Introductory Econometrics: A Modern Approach; Nelson Education: Toronto, ON, Canada, 2015.

50. Chinese National Meteorological Information Center. Available online: http://data.cma.cn (accessed on 2 September 2016).

51. Li, Y.; Li, W. China's Rangeland Management Policy Debates: What Have We learned? Rangel. Ecol. Manag. 2015, 68, 305-314.

52. Bartolome, J.W. Application of herbivore optimization theory to rangelands of the western United States. Ecol. Appl. 1993, 3, 27-29. [CrossRef] [PubMed]

53. Gao, X.; Wang, M.; Filippo, G. Climate change over China in the 21st century as simulated by BCC_CSM1.1-RegCM4.0. Atmos. Ocean. Sci. Lett. 2013, 6, 381-386.

54. Zhang, G.; Kang, Y.; Han, G.; Sakurai, K. Effect of climate change over the past half century on the distribution, extent and NPP of ecosystems of Inner Mongolia. Glob. Chang. Biol. 2011, 17, 377-389. [CrossRef]

55. Neupert, R.F. Population, nomadic pastoralism and the environment in the mongolian plateau. Popul. Environ. 1999, 20, 413-441. [CrossRef]

56. Sun, X.; Ao, R.; Erden, U. Study on human population migration in the pastoral region of Xilingol League. 2009. Available online: http://d.wanfangdata.com.cn/conference/7622213 (accessed on 2 September 2016). (In Chinese)

57. Wang, X.; Chen, F.; Dong, Z. The relative role of climatic and human factors in desertification in semiarid China. Glob. Environ. Chang. 2006, 16, 48-57. [CrossRef]

58. Friedel, M.H.; Sparrow, A.D.; Kinloch, J.E.; Tongway, D.J. Degradation and recovery processes in arid grazing lands of central Australia. Part 2: Vegetation. J. Arid Environ. 2003, 55, 327-348. [CrossRef]

59. Asefa, D.T.; Oba, G.; Weladji, R.B.; Colman, J.E. An assessment of restoration of biodiversity in degraded high mountain grazing lands in northern Ethiopia. Land Degrad. Dev. 2003, 14, 25-38. [CrossRef]

(C) 2017 by the authors. Licensee MDPI, Basel, Switzerland. This article is an open access article distributed under the terms and conditions of the Creative Commons Attribution (CC BY) license (http:/ / creativecommons.org/licenses/by/4.0/). 